\title{
107 航技研の飛行シミュレータ用ハーフドームとその応用例について
}

\section{若色 薰”、渡辺 顯}

\section{航空宇宙技術研究所 制御部 飛行シミュレーション研究室}

The NAL's half dome type display system for the flight simulator and its application

Kaoru Wakairo and Akira Watanabe ( National Aerospace Laboratory )

Abstract

A visual sense is an important information source for aircraft pilots. In a modern flight simulator, the image made by computer graphics is used as a visual information. Several equipment which artificial visual information are used as a flight simulator visual system. First, we present display systems for a flight simulator. Next, the half dome type display system which is installed to the National Aerospace Laboratory is explained. Finally, the evaluation results and its application is described.

\section{1.はじめに}

パイロットが航空機を操縦する場合、視界は重要な情 報源である。現代の飛行シミュレータでは、コンピュー タグラフィックス技術により作成した映像が視界情報と して用いられている。そのため飛行シミュレータでは、 人工的に作られた視覚情報を表示寸るための装置が各種 使用されている。Fig. 1 に飛行シミュレータ（航空宇宙 技術研究所所有）の外観を示寸。

本報告では、はじめに各種飛行シミュレータ用視界表 示装置について示し、次に航空宇宙技術研究所に設置さ れた飛行シミュレータ用ハーフドームに関して述べ、最 後にその評価と応用例について述べる。

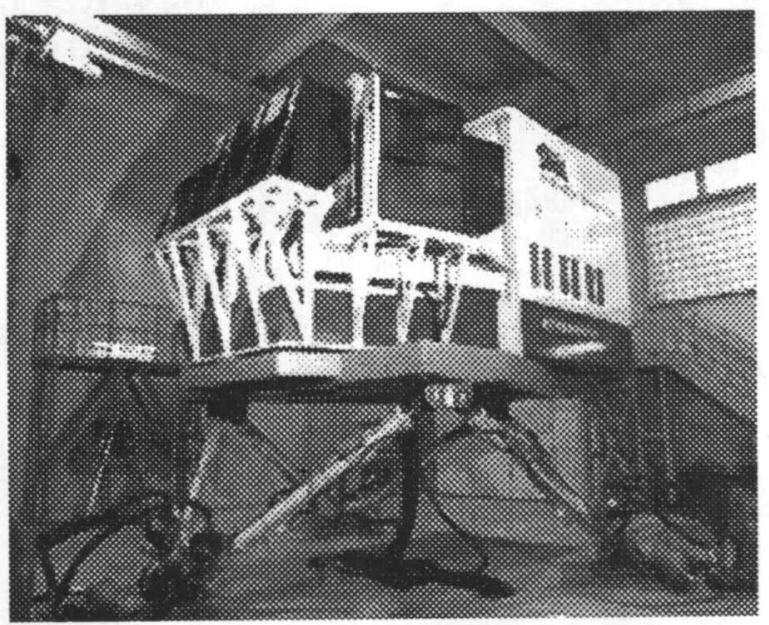

Fig. 1 Example of the flight simulator.

\section{2. 飛行シミュレータ用模擬視界装置}

パイロットが航空機を操繸する場合、操縦席の空から 見える外界の景色は、視界情報とも呼ばれ、重要な情報 源の一つとなっている。飛行シミュレータは、地上にお いて航空機の操綐模擬を可能とする装置であり、視界情
報の模擬は重要な構成要素として位置づけられる。飛行 シミュレータでは、視界情報の発生と表示を行う構成要 素を模擬視界装置 ${ }^{1}$ と総称している。模擬視界装置は、 視界映像の発生を行う視界映像発生装置と表示を行う視 界表示装置から構成される。以下にその詳細を述べる。

\section{1 視界映像発生装置}

視界情報の発生に用いる視界映像発生装置 (イメージ ジェネレータ : Image Generator、CGI : Computer Gener ated Imageryとも称される。）は、コンピュータグラフ イックス技術の粋を集めた装置である。視界映像発生装 置は、1980 年代以降、コンピュータグラフィックス 技術の進歩とともに年々性能向上が図られてきた。

現在、当所で用いている視界映像発生装置 ${ }^{2}$ の主要な 性能をFig. 2 に示す。

\begin{tabular}{|c|c|}
\hline 項目 & 纴粶 \\
\hline 㯕理名/メーカー & $\mathrm{PT} 2000 \mathrm{~s} \mathrm{~J} /$ 東芝テスコ料 \\
\hline チャンネル数 & 6 \\
\hline ポリコン数 & $2000 / チ+ネ ル$ \\
\hline 画像更斯レート & $6 \mathrm{OHz}$ \\
\hline 画俚発生遲九 & $67 \mathrm{msec}$ \\
\hline カラーテーフル & 8 理 $\times 256$ 色 \\
\hline テクスチャ & カラー96相 $(256 \times 256)$ \\
\hline ヒクセル数 & 1. $25 \mathrm{M} /$ 子十ネル \\
\hline 木子スト1/F & リフレクティフメモリ、イーサネット \\
\hline 特制棵能 & 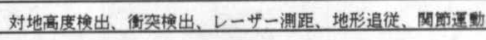 \\
\hline 移野物体 & 24 \\
\hline 天熼・日嵒 & 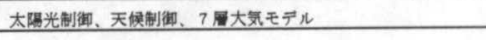 \\
\hline 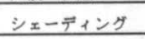 & 平面、曲面 \\
\hline 奵火椇港 & 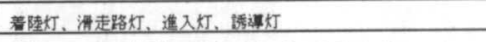 \\
\hline$\vec{F}$-夕作成 & 専用システム、汎用システム $(M u 1 t$ i Gen $)$ \\
\hline
\end{tabular}

Fig. 2 The specification of the NAL visual system.

\section{2 視界表示装置}

視界映像発生装置で作られた視界情報は映像信号の形 式で出力され、視界表示装置により視覚情報としてパイ ロットに呈示される。飛行シミュレータで電気的な視界 
表示装置が用いられたのは、 60 年代以降になって、テ レビジョン技術の向上とともに高性能なテレビジョンカ メラと C R Tディスプレイが開発された結果である。ち なみに当時の視界映像発生装置は、箱庭型の模型をテレ ビカメラで撮影する方式であった。

現在の視界表示装置は、プロジェクタによりスクリー ンに投影された映像を直視するスクリーン投写方式と凸 レンズや凹面鏡などの光学系を用いることで見かけ上の 焦点距離を遠くにさせる無限遠方式に大別される。Fig. 3 に視界表示装置の分類を示す。

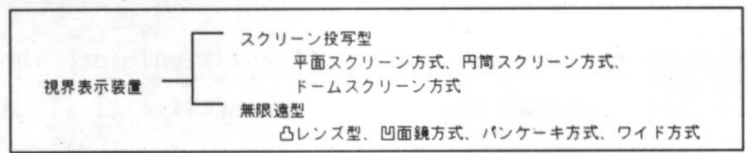

Fig. 3 The classification of the display system for the flight simulator.

\section{3. 飛行シミュレータ用ハーフドーム}

当所の飛行シミュレータ用ハーフドーム ${ }^{2)}$ は、先に述 べたスクリーン投写型ドームスクリーン方式に分類され る視界表示装置である。

この飛行シミュレータ用ハーフドームの特徴を次に示 す。

1) スクリーン面が完全球体ではなく部分球（半球の 約 8 割）であり、暗室内に設置している。

2 ) スクリーン全体に高輝度かつ高精細度の映像表示 を行うため、1000ルーメンクラスのビデオプ ロジェクタを 6 台使用している。

3) 視野角はヘリコプター用として下方視野を重視し ている。(左右 90 度、上方 30 度、下方 50 度) この特徴あるハーフドームの外観図をFig. 4 に示す。 また、その構成要素については、次章で詳細を述べる。



Fig. 4 The appearance of the half dome type display system

\section{1 スクリーン部}

スクリーンは、球面に加エした硬質アルミパネルを 枚組み合わせてスクリーン基材とし、スクリーンゲイン 1.5のスクリーン用塗料を吹き付け塗装により塗布し 作り上げた。スクリーン面における輝度測定結果をFig. 5 に示す。

なお、アルミパネルの組立と塗装作業は、当所のハー フドーム設置場所で行われた。

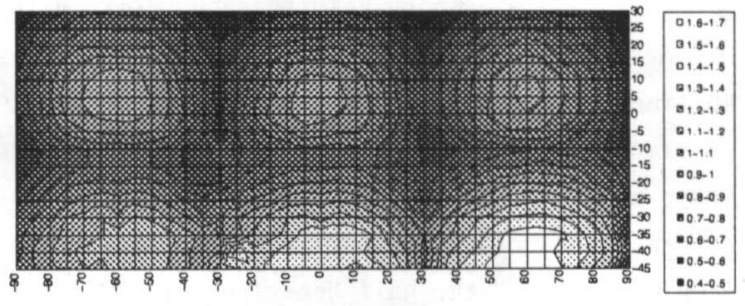

Fig. 5 Illumination map

\section{2 D I U 部}

D D I U (Digital Display Interface Unit)は、視界

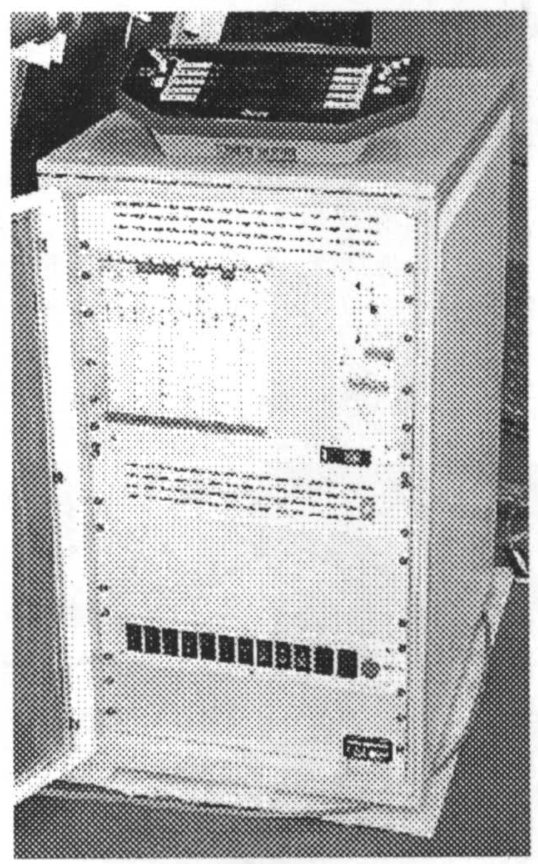
映像発生装置と プロジェクタの 間に設けられた 装置である。D D I Uは、6 台 のプロジェクタ が映し出す視界 映像をなめらか に接合して一つ の視界映像とし て表現する機能 と、そのために 必要となる個々 のプロジェクタ に対する調整機 能を持っている。 D D I Uの外観 をFig. 6 に示す。

Fig. 6 The appearance of the DDIU

3. 3 プロジェクタ部

プロジェクタ3゙は、飛行シミュレータ用として製品化 したものを使用している。

プロジェクタの色調、輝度、コンバーゼンスなど、ビ デオ系統の基本調整は、D D I Uに付属したリモートコ ントローラを用いて遠隔操作で行える。

また、ドームスクリーンに映像を投写する際に不可欠 な球面補正は、プロジェクタが持つ補正機能を用いて実 現している。プロジェクタの機能をFig. 7 に示す。 


\begin{tabular}{|c|c|}
\hline 買目 & 仕棬 \\
\hline 枉理名/メーカー & SEOS-911 フロジタタ/SEOS社(イギリス) \\
\hline 投写方式 & 3管3レンス方式 \\
\hline CRT & 商精細度洨冷式9インチ西醋フネーカスCRT \\
\hline 光出力 & 1100 ルーメン (10\%ヒークホワイト) \\
\hline レンス & 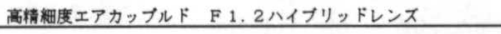 \\
\hline 解媛度 & 1000 本以上 ( RGB入力時) $/ 2500 \times 2000$ ヒクセル \\
\hline スクリーンサイス &  \\
\hline 搜查周波数 睡监 & 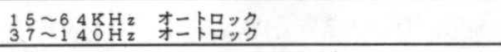 \\
\hline 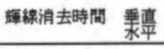 & $\begin{array}{l}2.5 \mu \mathrm{s} \\
2.00 \mu \mathrm{s} \\
\end{array}$ \\
\hline RGB带域 & $70 \mathrm{MHz}$ \\
\hline コンバージェンス & $\pi-1 / \nabla=2 ア ル$ \\
\hline$\lambda 力$ & R.G. Bビデオ值昌 $0.7 V_{P-P}$ \\
\hline 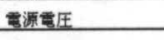 & $230 \mathrm{~V}$ \\
\hline 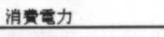 & $600 \mathrm{~W}$ \\
\hline 寸法 & 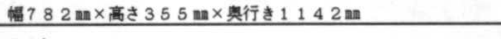 \\
\hline 重音 & $72 \mathrm{~kg}$ \\
\hline
\end{tabular}

Fig. 7 The specification for the Projector system

\section{4. 飛行シミュレータ用ハーフドームの評価}

ハーフドームの供用開始に際し、当所および機体製造 会社のテストパイロット（15名）を被験者として評価 実験 ${ }^{4)}$ を行った。評価結果をFig. 8 に示すが、項目のう ち視野角から輝度むらまでは表示性能の評価で、高度感 以降は全般的な感覚的評価となっている。表示性能に関 しては、全体的に評価が高いが、感覚的評価が低くなっ ており、今後の課題となっている。

また、この評価項目にはないが、一部の被験者に、め まい、不快感、吐き気などを感じる症状（シミュレータ 酔いと呼ばれる場合もある。）が現れた。

この症状は、他のドーム型視界表示装置でも、発生傾 向が見られ、視野角の広さがその一因ともいわれており、 この点についても課題を残している。

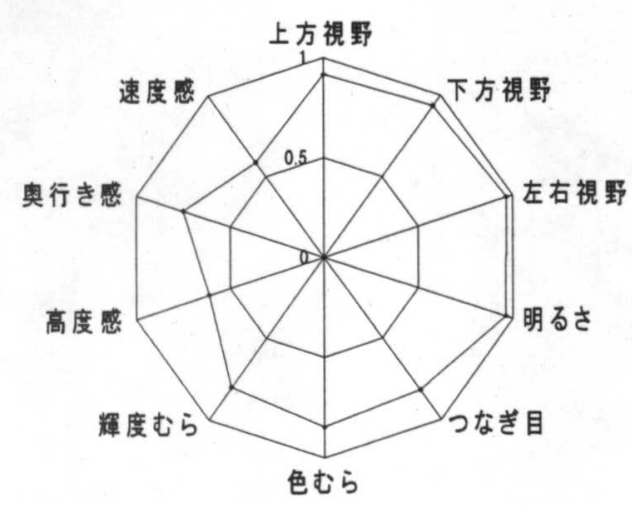

Fig. 8 The evaluation test result

\section{5. 飛行シミュレータ用ハーフドームの応用例}

ハーフドームは、広視野角、高輝度、高精細度の視界 表示装置である。この特性を生かして、飛行シミュレー ションをはじめとして、その利用分野が広がっており、 その応用例を次に述べる。
5. 1 ヘリコプターの飛行シミュレーション

$$
\text { ハーフドームは、ヘリコプター型飛行シミュレータ用 }
$$

視界表示装置として整備したもので、ヘリコプター用と

しては、十分な性能を有している。

最近の利用例としては、消防へリコプターの開発(1)に

利用された。その際の表示映像例をFig. 9 に示す。

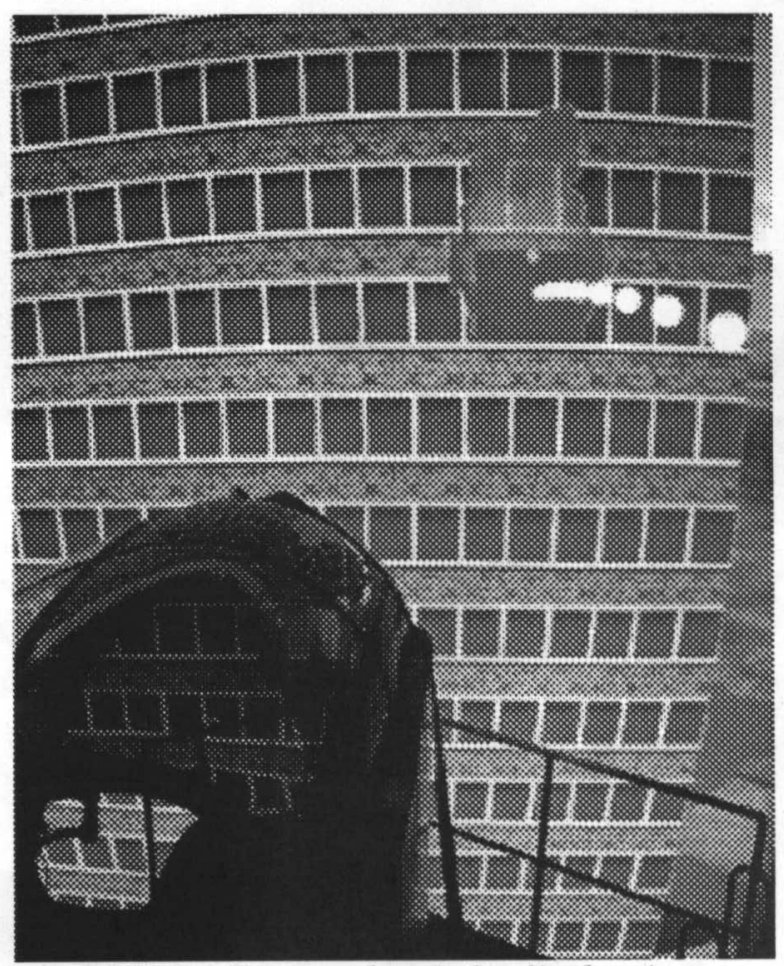

Fig. 9 The example of the display image (helicopter simulation)

\section{2 宇宙関連}

宇宙関連としては、宇宙構造物の景観シミュレーショ ンやテレイグジスタンスなどの遠隔操縦に関するシミュ レーションが予定されている。

宇宙関連の表示映像例をFig. 10に示す。

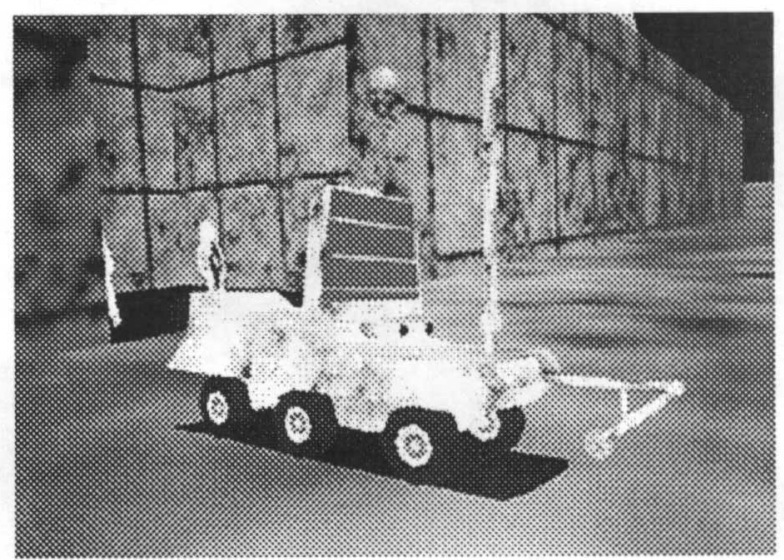

Fig. 10 The example of the display image (Lunar Rover) 
4. 3 人間工学・生理学

ヘリコプターなどの飛行シミュレーション以外への利 用としては、視野角の広さを必要とする分野 ${ }^{61}{ }^{71}$ への広 がりを見せている。この表示領域については、人間の視 野領域をほとんどカバーするため、人間工学的な実験へ の適用が多い。その際の表示映像例をFig. 11に示す。

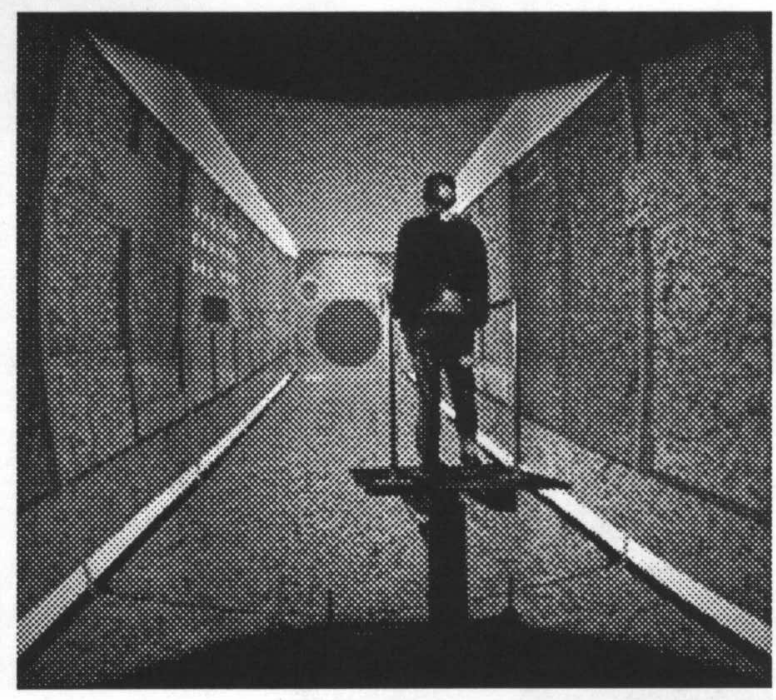

Fig. 11 The example of the display image

\section{6. まとめ}

本ハーフドームは、広視野角、高輝度、高精細度の視 界表示装置として、飛行シミュレーションをはじめとし て、他分野への適用も広がっている。今後も航空機の飛 行シミュレーションだけにとらわれず、他分野における 実験についても広く解放してゆきたい。

最後に、ドーム型ディスプレイの将来構想として、大 型自発光方式の設備も検討していることを述べておきた い。Fig. 12にその外観を示す。

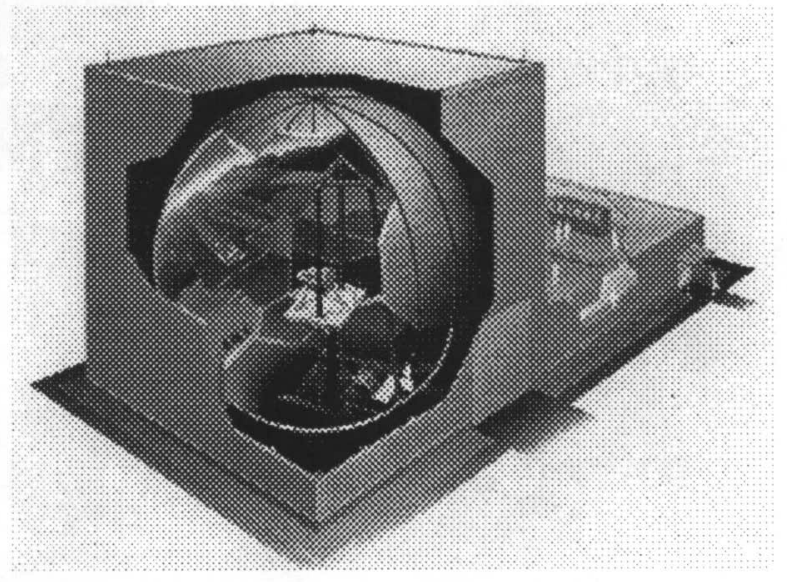

Fig. 12 The futuristic dome display system

\section{参考文献}

1) 渡辺顯 : 飛行シミュレータと最近の視界装置、 日本航空宇宙学会誌、第 4 巻 第491号、 pp. 702 709、（1994）

$2 ）$ 東芝テスコ株：P T $2000 \mathrm{~S} \mathrm{~J}$ 取扱説明書、1995

3 ) SEOS DISPLAY LTD : SEOS-911 Projector 資料

4 ) 若色、他 : 大型ハーフドーム視界表示装置の性能と 評価について、日本機械学会

第 4 回交通・物流部門大会講演論文集、pp. 175 176、 1995. 12

5 ) 舩引、他 : ヘリコプタによるビル火災消火の模擬実 験（その 3 )、航空宇宙技術研究所報告、TR-1308、 1996. 10

6 ) 航空宇宙技術研究所、他; 宇宙における錯覚・失認 対策法に関する研究 (その 3 )、

宇宙開発事業団宇宙環境利用システム本部

平成 6 年度個別研究成果報告、 1995

7 ) 竹田、他 : 大型ディスプレイによる重心動摇の影響、 計測自動制御学会ヒューマン・インターフェイス部 会第 39 回研究会講演集、pp. 259 300、1996 